\title{
POPULATION ABUNDANCE OF ANTELOPES BASED ON PREVALENCE IN SOME SELECTED MARKETS IN RIVERS STATE, NIGERIA
}

\author{
G. Ibiso, G. C. Akani, Nioking A. and Glorious C. Onuegbu \\ Applied and Environmental Biology, Rivers State University \\ Animal and Environmental Biology, Rivers State University
}

\begin{abstract}
Cite this article:
Ibiso G., Akani G.,C. , Nioking A., Glorious C. O. (2021), Population Abundance of Antelopes Based on Prevalence in Some Selected Markets in Rivers State, Nigeria. African Journal of Environment and Natural Science Research 4(3), 45-47. DOI: 10.52589/AJENSRLJSUKZEA.
\end{abstract}

\section{Manuscript History}

Received: 10 March 2021

Accepted: 14 April 2021

Published: 12 July 2021

Copyright $(\odot) 2020$ The Author(s). This is an Open Access article distributed under the terms of Creative Commons AttributionNonCommercial-NoDerivatives 4.0 International (CC BY-NC-ND 4.0), which permits anyone to share, use, reproduce and redistribute in any medium, provided the original author and source are credited.
ABSTRACT: This study was conducted to investigate the population abundance of antelopes based on prevalence in some selected bushmeat markets in Rivers State, Nigeria. Three (3) markets known to have a long history of wildlife marketing/business were chosen as sampling stations. These include: Omagwa bushmeat market, Imo River bushmeat market and As a market. The stations were visited twice a week for six (6) months, 6 times in a month (December 2017-February 2018) and 3 wet season months (May 2018-July 2018). Sample and data were collected in the morning hours between 7 am and 12 noon when hunters usually return with their bounty. During each visit, morphometric traits of antelope carcasses brought by hunters/bushmeat traders were measured with the aid of a measuring tape and weighed. The sex of each antelope was determined by examining the reproductive organs and the number of antelope carcasses brought to the market was recorded. A total count of 202 individuals belonging to 3 species-Cephalophus maxwelli, Neotragus batesi and Tragelaphus scriptus from the family Bovidae-were recorded from all the three stations, with $C$. maxwelli being the dominant species in all stations. C. maxwelli had a total count of 141 individuals while N. batesi and T. scriptus had total counts of 35 and 26 individuals respectively. Omagwa bushmeat market had the highest count of antelope carcasses accounting for 63\% (126 individuals) of the total count, followed by Imo River bushmeat market with 23\% (47 individuals) and Asa market with 14\% (29 individuals). A total of 103 males and 99 females were recorded. Seasonal variation data revealed that the dry season had a count of 72 individuals while the wet season had a count of 130 individuals. Combing of vegetation, night hunting, use of dart guns and use of snare traps were the dominant methods used in the study locations. According to the International Union for Conservation Nature (IUCN), these bovids are said to be the least-concern species but this research work showed that $T$. scriptus and N. batesi were threatened locally.

KEYWORDS: Bushmeat, Antelope, Market, Abun 


\section{INTRODUCTION}

An antelope is a member of a number of even-toed ungulate species indigenous to various regions in Africa and Eurasia. They belong to the Bovidae family (order Artiodactyla) and there are many different species of antelopes, including the tiny royal antelope that stands at the height of a rabbit. Antelopes account for over two-thirds of the approximately 135 species of hollow-horned ruminants (cud chewers) in the family Bovidae, which also includes cattle, sheep and goats. The size of an antelope ranges from $1 \mathrm{~m}$ to $1.5 \mathrm{~m}$ with an average weight of 500-900kg (Anonymous, 2008).

The sophistication of Rivers State ecological system — which includes the estuarine, mangrove forest, freshwater swamp and rainforest - that spreads across the state impacts the abundance and distribution of wildlife resource, and as well affects the behavior of wildlife species and the cultural disposition of the people (Powell, 1993; Akani, 2008).

The antelope is one of the many medium-sized mammals holding the African food chain together. Antelopes are also a significant component of the fauna which attracts game-viewing tourists to Africa's better-known National Parks and reserves (Skinner, 1973). Some antelopes, such as the giant eland, giant sable, gemsbok, scimitar-horned oryx and addax are flagship species for the conservation of important wildlife areas in Africa, a role which is exhibited more generally by species such as the elephant and lion (O'connor and Kruger, 2003).

\section{LITERATURE REVIEW}

Several species of antelope are native to Africa than other continents, especially savannahs with 20-35 species occurring in East Africa (Bro-Jorgensen \& Mallon, 2016). The savannah habitat in Africa has expanded and contracted five times over the last three million years, and the fossil record indicates this is when most extant species evolved. It is believed that isolation in refugia during contractions was a major driver of this diversification (Vrba \& Elisabeth, 1995). Other species occur in Asia - the Arabian Peninsula is home to the Arabian oryx and Dorcas gazelle; India is home to the Nilgai, chinkara, blackbuck, Tibetan antelope and fourhorned antelope; while Russia and Central Asia have the Tibetan antelope and Saiga. Many species of antelopes have been imported to other parts of the world, especially the United States, for exotic game hunting. Antelopes live in a wide range of habitats. Numerically, most live in the African savannahs. However, many species are more secluded, such as the forest antelope as well as the extreme cold-loving Saiga, the desert-adapted Arabian oryx, and semiaquatic sitatunga (Spinage, 1986). Species living in forests, woodlands, or bushes tend to be sedentary, but many of the plains species undertake long migrations. These enable grasseating species to follow the rains and by extension, their food supply. The Gazelles of East Africa perform some of the most impressive mass migratory circuits of all mammals (Estes, 1992). Antelopes vary greatly in size. For example, a male Eland can measure $178 \mathrm{~cm}$ (70 in) at the shoulder and weigh almost $950 \mathrm{~kg}(2,090 \mathrm{lb}$.), whereas an adult royal antelope may stand only $24 \mathrm{~cm}(9.4 \mathrm{in})$ at the shoulder and weigh a mere $1.5 \mathrm{~kg}$ (Bothma et al., 2010). Antelopes have a wide variety of coverings, though most have a dense coat of short fur. In most species, the coat (pelage) is some variation of brown (or several shades of brown), often with white or pale underbodies. Exceptions include the Zebra-marked Zebra duiker, the grey, black and white Jentink's duiker, and the black lechwe. Most of the "spiral-horned" antelopes have pale, vertical stripes on their backs (Cowlishaw et al., 2005). Many desert and semi-desert species are 
particularly pale, some almost silvery or whitish (e.g. Arabian oryx); the beisa and southern oryxes have gray and black pelages with vivid black-and-white faces (Estes et al., 2008). Common features of various Gazelles are white rumps, which flash a warning to others when they run from danger, and dark stripes mid-body (the latter feature is also shared by the Springbok and Beira). The Springbok also has a pouch of white brush-like hairs running along its back, which opens up when the animal senses danger, causing the dorsal hairs to stand on end (Gerard et al., 2002)

\section{MATERIALS AND METHOD}

\section{Description of Study Area}

This research was carried out in some selected Bushmeat markets in Rivers State, Nigeria, West Africa. Rivers state is located on latitude $4.5^{\circ}$ North, $6.5^{\circ}$ East and longitude $4.75^{\circ}$ North, $6.83^{\circ}$ East with Port Harcourt as her headquarters (latitude $4.77742^{\circ}$, longitude $7.0134^{\circ}$ ), having an estimate of about 5,185,400 human inhabitants and a total geographical area of about $11,077 \mathrm{~km}$, with a density of $468 / \mathrm{km}$. Rivers State is made up of 23 local government areas. The state has a long history of association with wildlife; this is shown below:

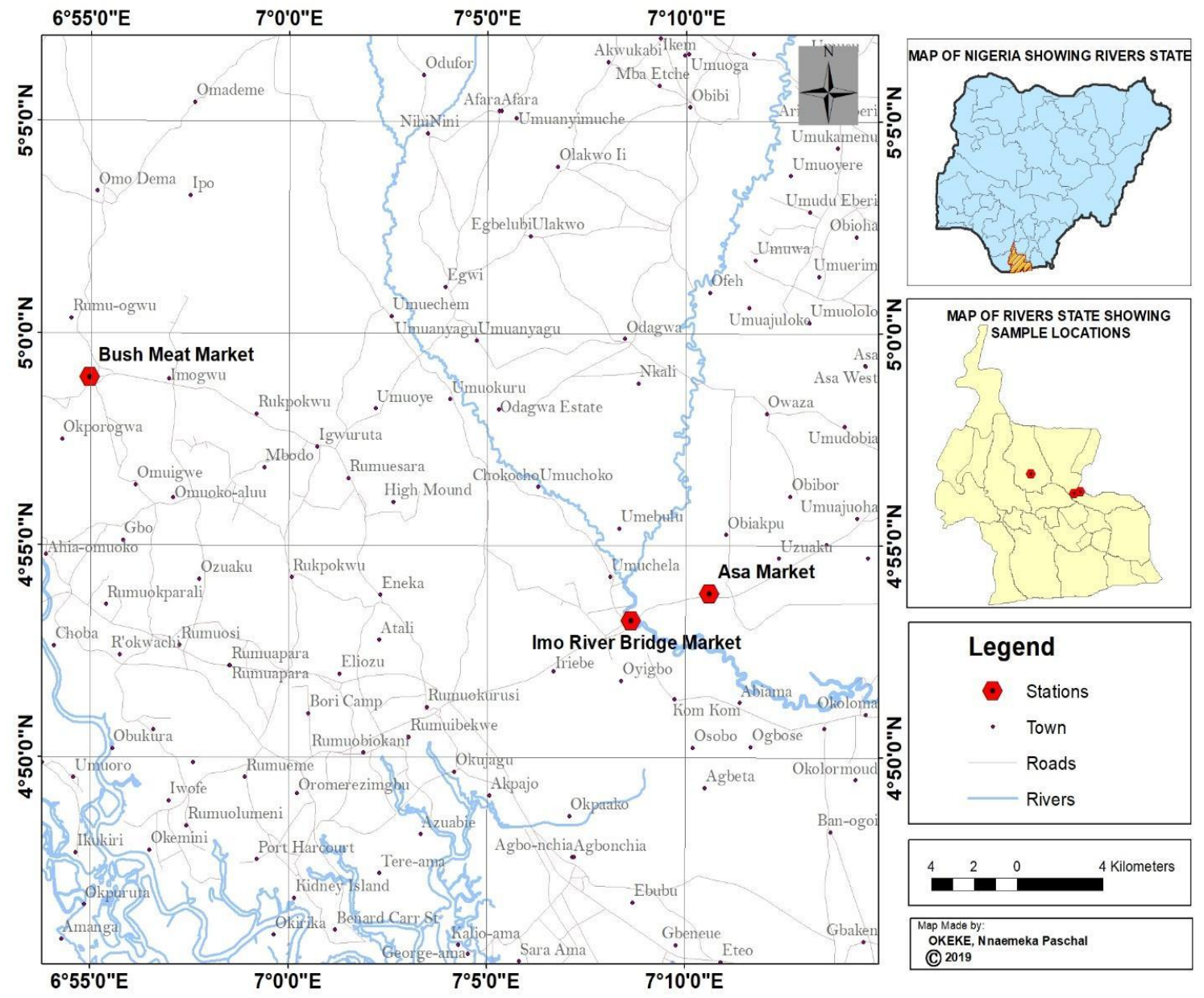

Fig 3.1 Map of Study Area Showing the Sample Station 


\section{Sampling/Data Collection}

\section{Asa Bushmeat Market/Imo River Bridge Bushmeat Market}

Data collection was achieved by waiting for the arrival of traditional hunters as well as farmers who hunt with traps, bows and arrows, as well as guns. This research area (Fig. 1) was chosen because their traditional primary activities revolve around wildlife, hunting, poaching, bush meat trading and farming as a result of their vegetation and terrain. Also, these areas are associated with the old Rivers State Government Forest Reserve, the Upper and the Lower Otamiri Forest Reserve Ikwerre/Etche, the Upper and the Lower Imo River Forest Reserve Etche, Oyibo, and Daen Forest Reserve Khana/Eleme (Akani et al., 2015). Three bushmeat markets (Omagwa bushmeat market, Imo River Bridge bushmeat market and Asa market) were sampled for species of Antelopes during the dry season (December 2017-February 2018) and wet season (May 2018-July 2018) for a total period of six (6) months.

\section{Statistical Analysis}

For the purpose of this research, the statistical tests (descriptive statistics) were done using SAS (Statistical Analysis System), PASTEXCEL and STATISTICA package (one-way Anova) to describe and estimate the levels of abundance of antelope species available in the study location, and to ascertain the variation and conservation levels between species and sexes. These were done using (SPSS 2018) Version.

\section{RESULTS}

\section{Antelope Abundance and Diversity}

Table 4.1 shows the total number of antelopes recorded in each bushmeat market during the sampling duration. From the three (3) stations sampled, a total of 202 antelope carcasses were recorded. At station 1 (Omagwa bushmeat market), a total of 126 antelope carcasses were recorded, comprising Tragelaphus scriptus (24), Cephalophus maxwelli (82) and Neotragus batesi (20). In station 2 (Imo River bushmeat market), a total of 47 antelope carcasses were recorded-Tragelaphus scriptus (1), Cephalophus maxwelli (38) and Neotragus batesi (8). At Station 3 (Asa market), a total of 29 antelope carcasses were counted, comprising Tragelaphus scriptus (1), Cephalophus maxwelli (21) and Neotragus batesi (7). 
Table 4.1: Total Number of Antelopes Counted at Each Sampling Station during the Study

\begin{tabular}{|c|c|c|c|c|c|}
\hline $\begin{array}{c}\text { Serial } \\
\text { number }\end{array}$ & $\begin{array}{c}\text { Common } \\
\text { name }\end{array}$ & $\begin{array}{c}\text { Species } \\
1\end{array}$ & $\begin{array}{c}\text { Station 1 } \\
\text { (Omagwa) }\end{array}$ & $\begin{array}{c}\text { Station 2 } \\
\text { (Imo River) }\end{array}$ & $\begin{array}{c}\text { Station 3 } \\
\text { (Asa market) }\end{array}$ \\
\hline Bushbuck & $\begin{array}{c}\text { Tragelaphus } \\
\text { scriptus }\end{array}$ & 24 & 1 & 1 \\
\hline 3 & $\begin{array}{c}\text { Maxwells } \\
\text { duiker }\end{array}$ & $\begin{array}{c}\text { Cephalophus } \\
\text { maxwelli }\end{array}$ & 82 & 38 & 21 \\
\hline Total & $\begin{array}{c}\text { Dwarf } \\
\text { Antelope }\end{array}$ & $\begin{array}{c}\text { Neotragus } \\
\text { batesi }\end{array}$ & 20 & 8 & 7 \\
\hline
\end{tabular}

Table 4.2 shows the species diversity, abundance, sexual variation and conservation status of the antelope carcasses recorded from three sampled bushmeat markets in Rivers State, Nigeria. Tragelaphus scriptus had an abundance of 26 individuals across stations with 10 females and 16 males, Cephalophus maxwelli had an abundance of 141 individuals with 71 females and 70 males, and Neotragus batesi had an abundance of 35 individuals with 17 males and 18 females. A total of 202 individuals were recorded with 99 being females and 103 males.

Table 4.3 shows species diversity, abundance, sexual variation and conservation status of the community of antelopes recorded from three sampled bushmeat markets in Rivers State, Nigeria. A total of 24 species of T. scriptus were counted in Omagwa bushmeat market-15 males and 12 females, while 1 female was recorded for Imo River bushmeat market and 1 male recorded for Asa market.

C. maxwelli had a total count of 82 individuals in Omagwa bushmeat market -43 males and 39 females, while Imo River bushmeat market had a count of 14 males and 2 females. Asa market recorded a count of 21, having 13 males and 8 females.

Neotragus batesi count totalled 20 individuals in Omagwa - 7 males and 13 females, Imo River bushmeat market had a count of 8 individuals -6 males and 7 females. The count from Asa market was 7-3males and 4 females.

Table 4.4 shows seasonal variation in the abundance of antelopes documented from the selected bushmeat markets of Rivers State. Tragelaphus scriptus had 11 counts during the dry season and 15 counts during the wet season. Cephalophus maxwelli had a count of 51 during the dry season and 90 during the wet season. Neotragus batesi had a count of 10 individuals during the dry season and 25 individuals during the wet season 
Table 4.2: Sexual Variation and Conservation Status of Antelopes Recorded from Three Sampled Bushmeat Markets in Rivers State Nigeria

\begin{tabular}{llllccc|c|}
\hline S/N & Common name & Species & Abundance & Male & Female & Status \\
\hline 1 & Bushbuck & \multicolumn{2}{c}{ Tragelaphus scriptus } & 26 & 16 & 10 & \multicolumn{1}{c}{ LC } \\
\hline 2 & Maxwell's duiker & Cephalophus maxwelli & 141 & 70 & 71 & LC \\
\hline 3 & Dwarf antelope & Neotragus batesi & 35 & 17 & 18 & LC \\
\hline \multicolumn{2}{|l|}{ Total $=$} & $\mathbf{2 0 2}$ & $\mathbf{1 0 3}$ & $\mathbf{9 9}$ & \\
\hline
\end{tabular}

Table 4.3: Sexual Variation of Antelopes Recorded from the Three Stations of Bushmeat Markets Sampled in Rivers State, Nigeria

\begin{tabular}{llccccccccc}
\hline $\begin{array}{c}\text { S/ } \\
\text { N }\end{array}$ & \multicolumn{1}{c}{ Species } & Omagwa & M & F & $\begin{array}{c}\text { Imo } \\
\text { River }\end{array}$ & M & F & $\begin{array}{c}\text { Asa } \\
\text { Market }\end{array}$ & M & F \\
\hline \multirow{2}{*}{$\begin{array}{l}\text { Tragelaphus } \\
\text { scriptus }\end{array}$} & 24 & 1 & 9 & 1 & 0 & 1 & 1 & 1 & 0 \\
2 & & 5 & & & & & & & \\
2 & $\begin{array}{l}\text { Cephalophus } \\
\text { maxwelli }\end{array}$ & 82 & 4 & 3 & 38 & 1 & 2 & 21 & 1 & 8 \\
3 & Neotragus batesi & 20 & 7 & 1 & 8 & 2 & 6 & 7 & 3 & 4 \\
\hline
\end{tabular}

Table 4.4: Seasonal Variation in the Abundance of Antelopes Documented from the Selected Bushmeat Markets of Rivers State

\begin{tabular}{|l|l|l|c|c|}
\hline S/N & Family & Species & \multicolumn{2}{|c|}{ Seasonality } \\
& & & Dry \\
\hline 1 & Bovidae & Tragelaphus scriptus & 11 & 15 \\
\hline 2 & Bovidae & Cephalophus maxwelli & 51 & 90 \\
\hline 3 & Bovidae & Neotragus batesi & 10 & 25 \\
\hline Total= & & & $\mathbf{7 2}$ & $\mathbf{1 3 0}$ \\
\hline
\end{tabular}

\section{Market Value of Antelope}

Figure 4.1 shows the percentage abundance of individuals recorded across the three sampled bushmeat markets of Rivers State, Nigeria. Omagwa bushmeat market recorded the highest percentage abundance of $63 \%$ (126) individuals out of the total number of 202 recorded, Imo River market had a percentage abundance of 23\% (47), while Asa market had a percentage abundance of $14 \%$ accounting for 29 individuals. 
Figure 4.2 shows the antelope species composition and percentage abundance of the three sampled bushmeat markets of Rivers State. Cephalophus maxwelli had the highest species composition of 141 antelope carcasses accounting for 70\%, followed by Neotragus batesi with a species composition of 35 antelope carcasses accounting for $17 \%$ and Tragelaphus scriptus with the least -26 carcasses $(13 \%)$.

Table 4.5 shows the market value of antelope carcasses by station. A survey of the study stations reveals that there was no unanimous price tag for each antelope carcass brought to the study stations. However, there was a range of prices that were dependent on the size, societal importance and cost of wild animals. This range of prices was seen to be almost the same across the study stations.

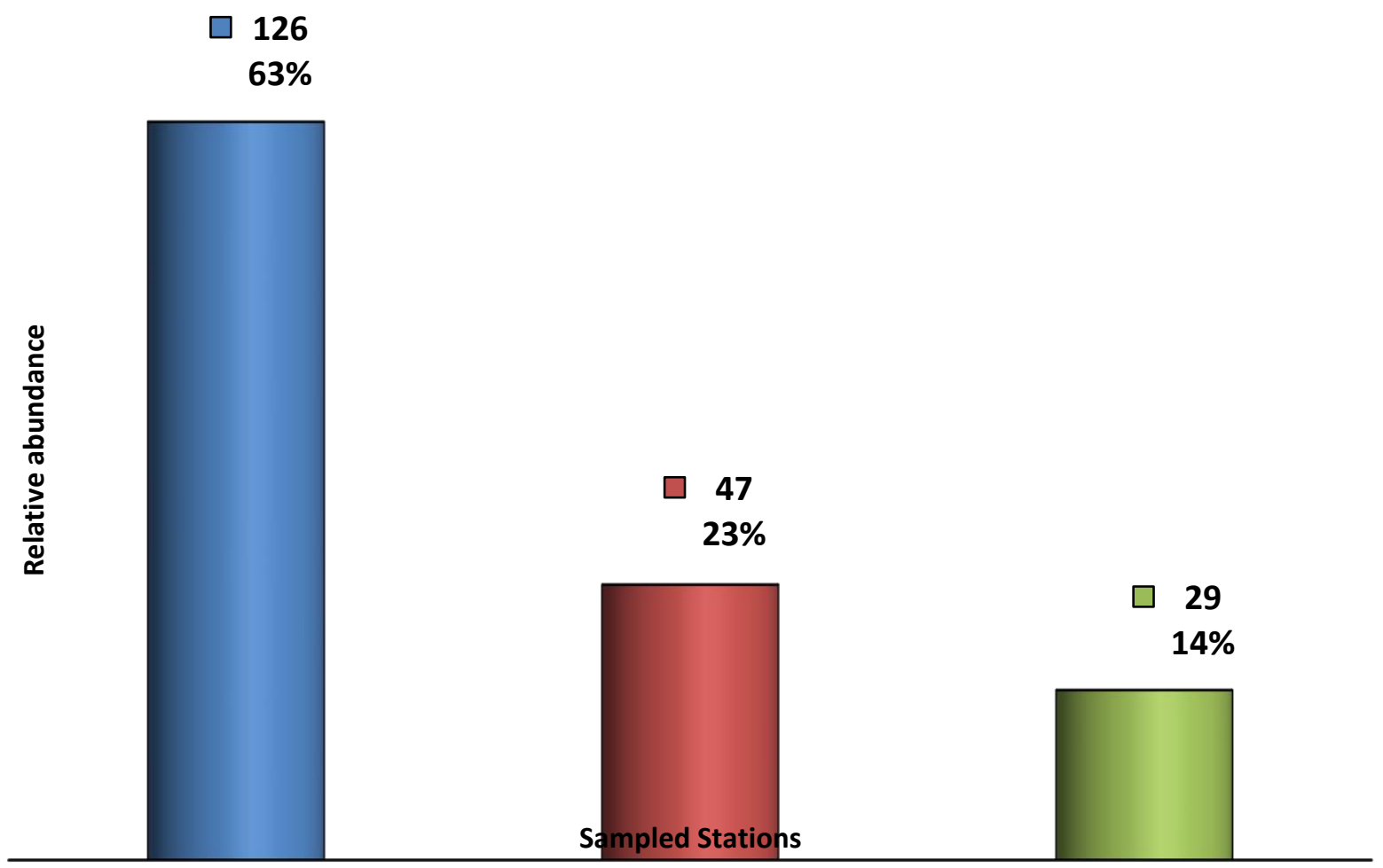

Figure 4.1: Percentage Abundance of Antelope Carcasses Recorded across the three Sampled Bushmeat Markets of Rivers State, Nigeria 


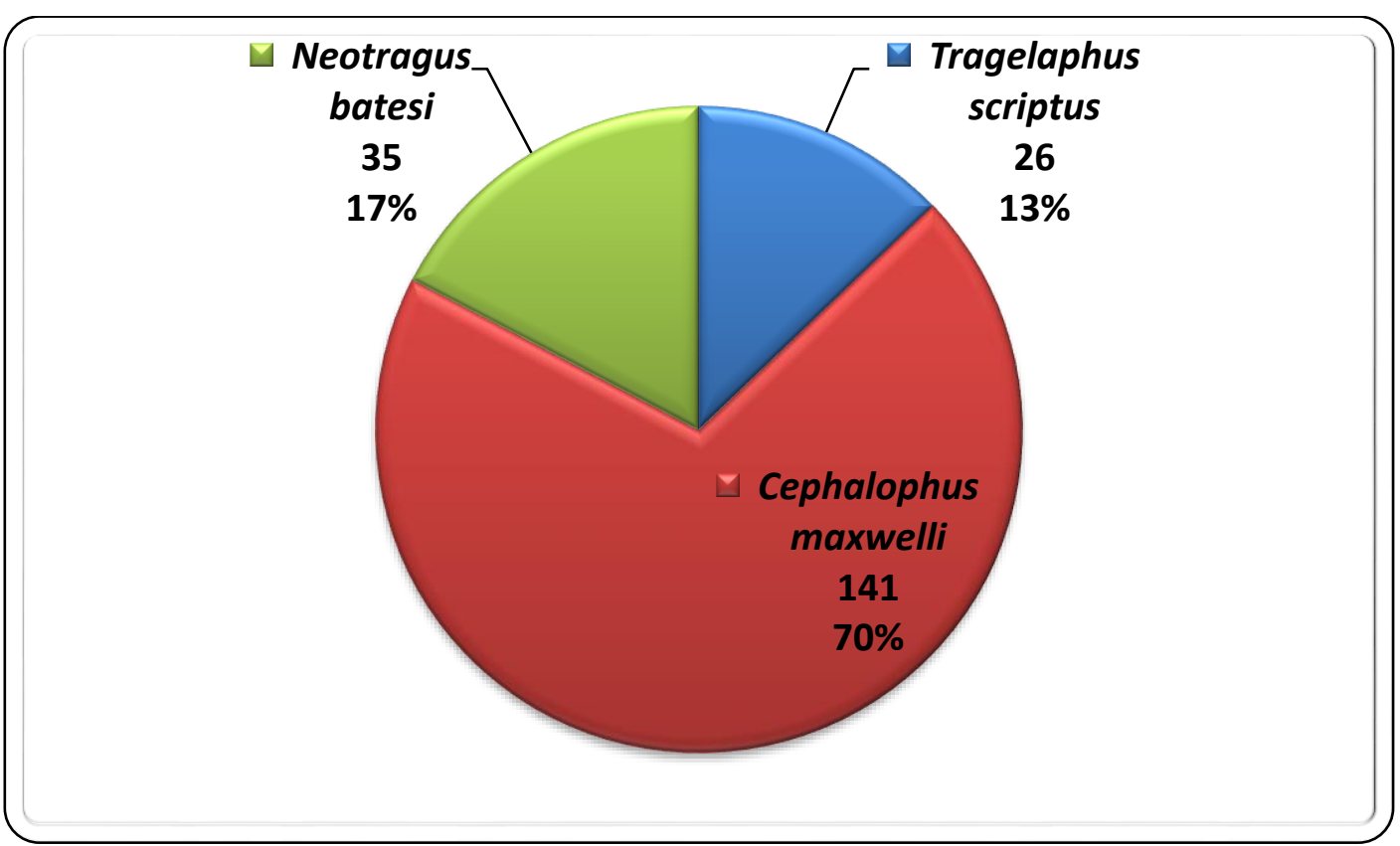

Figure 4.2: Antelope Species Composition and Percentage Abundance of the three Sampled Bushmeat Markets of Rivers State

Table 4.5 Market Value of Antelope Carcasses by Station

\begin{tabular}{|l|l|l|l|l|}
\hline S/No & Antelope Species & Station & $\begin{array}{c}\text { Price Range } \\
\text { (\#) }\end{array}$ & Mean Price \\
\hline $\mathbf{1}$ & Cephalophus & Omagwa & $6,000-11,000$ & 7,500 \\
& maxwelli & Imo River & $7,000-9,000$ & 8,000 \\
& & Asa Market & $6,800-10,000$ & 7,850 \\
\hline $\mathbf{2}$ & \multirow{2}{*}{ Neotragus batesi } & Omagwa & $5,000-8,000$ & 6,500 \\
& & Imo River & $4,500-8,000$ & 6,000 \\
& & Asa Market & $4,500-8,000$ & 6,000 \\
\hline $\mathbf{3}$ & \multirow{2}{*}{ Tragelaphus scriptus } & Omagwa & $14,000-25,000$ & 10,500 \\
& & Imo River & $8,500-13,500$ & 10,000 \\
& & Asa Market & $8,000-12,000$ & 9,500 \\
\hline
\end{tabular}

\subsection{Morphometric Characteristics of Antelope Species}

Table 4.6 shows the summary of the morphometric characteristics of the different species of antelopes across stations sampled during this study. The male and female Cephalophus maxwelli found in the three stations all had an average weight of $6.53 \mathrm{~kg}$ and a total length ranging from $26 \mathrm{~cm}$ to $28 \mathrm{~cm}$. Neotragus batesi found in the three stations all had an average weight of $5.11 \mathrm{~kg}$ and a total length ranging from $16 \mathrm{~cm}$ to $18 \mathrm{~cm}$. The male and female Tragelaphus scriptus found in the three stations all had an average weight of $50.68 \mathrm{~kg}$ and an average total length of $45.71 \mathrm{~cm}$. 
The length and weight of the male and female species of antelopes found in the study stations were analysed and compared. The linear regression length-weight graphs are shown in Fig 4.3 to 4.2 and the summary outlined in Table 4.7. Most of the female species sampled across stations exhibited a strong relationship between the length and weight of the antelope.

\section{DISCUSSION}

A total of three species of Antelopes were recorded at the study stations (Omagwa bushmeat market, Imo River bushmeat market and Asa bushmeat market) at two seasons - 3 dry season months (December 2017-February 2018) and 3 wet season months (May 2018-July 2018). A total of 202 antelopes were recorded from these three species of antelopes-Tragelaphus scriptus, Cephalophus maxwelli and Neotragus batesi). They are under various threats or endangered due to the low number that was recorded in some of the sample stations. The conservation status of a species is very important as it relates to its continuity in the environment. The report of this study revealed that the population size of antelopes in the study the density is low especially with low counts recorded in Tragelaphus scriptus and Neotragus batesi $-26 \%$ and $35 \%$ respectively - though of the total individuals recorded from the markets, this corresponds with the report of SSC/ASG/IUCN as compiled by East (1999), which label kob as being "vulnerable" in Nigeria, although the species recorded were different from the ones recorded in this study. However, when this is viewed on a national and global scale they may be vulnerable as the species is likely to be very rare elsewhere or outside the protected area (Clarke, 1983; Hunte et al., 2007).

The area sampled represents the major bushmeat markets in the state, where farming and hunting are the major occupations of the natives. Other bushmeat markets in the State include Nonwa bushmeat market, Akabuka and Mbiama. The study stations are characterized by dense vegetation cover resulting from high and longer annual rainfall and short sunshine duration. The area covered by vegetation (land cover) serves to obstruct vision, thereby providing a means of escape for the hunted animal and increasing foraging efficiency. This is in agreement with the finding of (Okiwelu et al., 2009) who by an interview with hunters revealed that the fast growth of vegetation in the rainy season limits the sightings of non-canopy dwelling wildlife, adversely affecting hunting effectiveness.

The result from table 4.3 shows that hunters believed that hunting in wet seasons was more productive than in the dry seasons. This implies the easiness of hunting in the wet season than in the dry season. According to respondents, the sound from dry grasses/vegetation during dry season provides a signalling effect that alerts the animal before the hunter approaches a stable shooting range.

There are also more escape routes available for the antelopes during the dry season than in the wet season, especially during flooding when the animal is unable to swim to dry land quickly before they are hunted down. This is in contrast with the study of (Nic et al., 2008) that antelopes are known for their water-loving behavior. This study revealed that the genus Sitatunga are amphibious antelopes associated with wetlands and are represented by three subspecies (T. gratus, $T$. selousi and $T$. spekei) that occur in the Congo basin, around Lake Victoria, and in the Bangweulu, Zambesi and Okavango basins; likewise in Rivers state, 
Nigeria. They have small home ranges close to water; when threatened by land-based predators, they submerge in water up to the level of their nostrils.

Results on table 4.1 show that there were more bushmeat carcasses at station 1 (Omagwa bushmeat market) as $126(63 \%)$ of the 202 antelopes counted were found here. This was followed by station 2 (Imo River bushmeat market) with a count of 47 (23\%), and station 3 (Asa market) with a count of 29 (14\%). The result shows that bushmeat carcasses were more abundant at station 1; it also shows an obvious decrease in the other two stations, with the least abundance recorded in station three (Asa market). A reason for this is likely that Omagwa bushmeat market serves as the major site for the trading of bushmeat across the catchment area. This result is in agreement with (Okiwelu et al., 2008) who found Omagwa to be one of the areas with intense bushmeat trading in Rivers State.

\section{CONCLUSION}

The study was conducted at three different bushmeat markets in Rivers State. Three (3) species of Antelopes were recorded: Cephalophus maxwelli, Tragelaphus scriptus and Neotragus batesi. A total of 202 individuals were recorded from the three (3) species of antelope carcasses from the study areas.

C. maxwelli was the dominant species in all stations sampled, thus accounting for 141 carcasses count from the 202 total counts recorded; this was followed by N. batesi (35). T. scriptus was the least dominant species with a total count of 26 carcases.

Wet season recorded a higher count on antelope carcasses seen, with a total of 130 antelope carcasses while dry season had a count of 72 carcases.

Station 1 (Omagwa bushmeat market) had the highest count of antelope traded recorded 126 (63\%), followed by station 2 (Imo River bushmeat market) with a count of 47 (23\%), while station 3 had the least count of 29 (14\%).

\section{RECOMMENDATIONS}

1. Hunting of wildlife is part of the daily life activities carried out by hunters from various communities who mostly depend on it for sustenance; however, hunters should reduce their hunting rates to enable regeneration of hunted wildlife species.

2. Government should plan the development of these areas to encourage sustainability of wildlife by creating forest reserves or patches, which will serve and cater for displaced wildlife.

3. Government, in the course of planning its conservation programs, should train individuals in various departments, targeted at controlling the size and species of animals that should be hunted at a particular season, considering their abundance.

4. Antelope farming should be encouraged in either reserve or in captivity by encouraging domestic ranching. 
5. Land tenure system should be endorsed as it will encourage the existence of wildlife in our surroundings.

\section{Contribution to knowledge}

1. This study confirms that $N$. batesi and T. scriptus are locally threatened although IUCN internationally reported that they are a lesser concern because they can still be found in other regions of the world.

2. This study also confirmed that $C$. maxwelli was still in abundance in Rivers State, Nigeria.

\section{REFERENCES}

Akani, G. C. (2008) Impact of petroleum industries activities on wildlife and biodiversity conservation in some states of the Niger Delta, Nigeria. Ph.D. Thesis, RSUST, Port Harcourt. 393pp.

Akani, G. C., Nioking, A., Edem, A. E., Luiselli, L.\& Fabio, P. (2015) Are mammal communities occurring at a regional scale reliably represented in "hub" bushmeat markets? A case study of Bayelsa State (Niger Delta, Nigeria).Folia Zoo 64(1) 79-86.

Bothma, J. du P., Van Rooyen, N.\& Du Toit, J. G. (2010). Antelope and other smaller herbivores. In Game Ranch Management, pp. 210-245.

Brashares, J. S., \& Arcese, P. (2002). Role of forage, habitat and predation in the behavioural plasticity of a small African antelope. Journal of Animal Ecology, 71(4), 626-638.

Brashares, J. S., Arcese, P., \& Sam, M. K. (2001). Human demography and reserve size predict wildlife extinction in West Africa. Proceedings of the Royal Society B: Biological Sciences, 268(1484), 2473-2478.

Bro-Jorgensen, J. \& Mallon, D.P. (2016).Antelope Conservation: From Diagnosis to Action (1 ed.). John Wiley \& Sons. pp. 163-164. ISBN 9781118409633. Archived from the original on 25 November 2017. Retrieved 9 July 2016.

IUCN. (2017). IUCN Red List of Threatened Species. Retrieved from www.iucnredlist.org

IUCN. (2009) IUCN Red List of Threatened Species. Version 2009.1, Gland, Switzerland.

Jadeja, S., Prasad, S., Quader, S, \& Isvaran, K. (2013). Antelope mating strategies facilitate invasion of grasslands by a woody weed. Oikos, 122(10), 1441-1452.

Janus, A.\& Jaeger, R. (2011). Country Profile Nigeria. 2011 Country Profiles, 1-8. Jarman, P. J. (1974). The Social Organisation of Antelope in Relation to Their Ecology. Behaviour, 48(1-4), 215-267.

Lameed, G.A. and Jenyo-Oni, A. (2012) Species-Diversity Utilization of Salt Lick Sites at Borgu Sector KLNP, Kainji. In: Lameed, G.A., Ed., Biodiversity Enrichment in a Diverse World, IntechOpen Limited, London, 35-62. https://doi.org/10.5772/3088

Lukey, J. R., Crawford, S. S., Gillis, D. J.\& Gillespie, M. G. (2011). Effect of ecological uncertainty on species at risk decision-making: COSEWIC expert opinion as a case study. Animal Conservation, 14(2), 151-157.

Magle, S. B., Hunt, V. M., Vernon, M.\& Crooks, K. R. (2012). Urban wildlife research: Past, present, and future. Biological Conservation. 5(1) 16-20 
Mallon, D.\& Kingswood, S. (2001). Global survey and regional action plans on antelope. Gland and Cambridge: IUCN. Retrieved from https://portals.iucn.org/library/efiles/documents/2001

Martin, A.and Caro, T. (2013). Illegal hunting in the Katavi-Rukwa ecosystem. African Journal of Ecology 5(2), 100-116.

McLoughlin, C. A.\& Owen-Smith, N. (2003). Viability of a diminishing roan antelope population: Predation is the threat. Animal Conservation, 6(3), 231-236.

Morgan, E. R., Lundervold, M., Medley, G. F., Shaikenov, B. S., Torgerson, P. R.\& MilnerGulland, E. J. (2006). Assessing risks of disease transmission between wildlife and livestock: The Saiga antelope as a case study. Biological Conservation, 131(2), 244 254.

Nasi, R., Taber, A. \& Vanvliet, N. (2011): Empty forests, empty stomachs? Bushmeats and livelihood in Congo and Amazon Basin. International Forest Research, 13, 355-368.

Obioha, E. E., Isiugo, P. N., Ikkaagba, E., Ngoufo, R., Bobo, K. S. \& Walter, M. (2012). Bushmeat harvesting and human subsistence nexus in Oban Hill Communities of Nigeria. Journal of Human Ecology,38,49-64.

O'connor, T.\& Kruger, S. (2003). Synchronous decline of populations of small antelope in a reserve in the southern Drakensberg, South Africa. South African Journal of Wildlife Research, 33(2), 97-107.

Okeke, J.J., Mogbo, T.C., Ufele, A.N., Nwankwo, O. D \& Nwosu. M.C. Survey of Wildlife Killed as Bush Meat in Otuocha and Environs, Anambra State, Nigeria. The Bioscientist: Vol. 1(2),127-131

Okiwelu, S. N., Enurum, N. \& Noutcha, M. A. E. (2008). Wildlife Harvest and Bushmeat trade in Rivers State, Nigeria-I-Species Composition, Seasonal Abundance and Cost.Scientia Africana, 14, 162-168.

Powell, C. B. (1993). Sites and Species of Conservation Interest in the Central Axis of the Niger Delta. Abuja, Natural Resource Conservation Council.

Prothero, Donald R. Robert M. Schoch (2002)Horns, Tusks anf Flippers. The Evolution of Hoofed Mammals 6(2), 49-83.patterns of habitat transformation and future threats to biodiversity in terrestrial ecosystems of the Cape Floristic Region, South Africa. Biological Conservation, 112(1-2), 63-85.

Ruggiero, R. G. (2002). Antelopes in Africa: bushmeat, game meat and wild meat - a question of sustainability. In Links between Biodiversity Conservation, Livelihoods and Food Security : The sustainable use of wild species for meat (pp. 72-84). Retrieved /IUCN_biodiversity_conservation_food_security.pdf

Sarkar, S., Pressey, R. L., Faith, D. P., Margules, C. R., Fuller, T., Stoms, D. M.\& Andelman, S. (2006). Biodiversity Conservation Planning Tools: Present Status and Challenges for the Future. Annual Review of Environment and Resources, 31(1), 123-159.

Struhsaker T.T. 1997. Ecology of an African rain forest: logging in Kibale and the conflict between conservation and exploitation. Gainesville: The University Press of Florida, $434 \mathrm{pp}$.

Shurter, S. (2015). Antelope Specialist Group. Gnusletter, 32(2), 7.

Skinner, J. D. (1973). An appraisal of the status of certain antelope for game farming in South Africa. Zeitschrift Für Tierzüchtung Und Züchtungsbiologie, 90(1-4), 263-277. 
African Journal of Environment and Natural Science Research

ISSN: 2689-9434

Volume 4, Issue 3, 2021 (pp. 45-57)

www.abjournals.org

Sparovek, G., Berndes, G., Barretto, A. G. de O. P.\& Klug, I. L. F. (2012). The revision of the Brazilian forest act: Increased deforestation or a historic step towards balancing agricultural development and nature conservation? Environmental Science and Policy, $16,65-72$.

Sodeinde, O.A. (1989) Dry Season Habitat Use by Senegal Kob in the Kainji Lake National Park, Nigeria. Mammalia , 53, 353-362. https://doi.org/10.1515/mamm.1989.53.3.353

Spinage, C. A. (1986). The Natural History of Antelopes. Facts on File Publications. New York. ISBN 0709944411 